\title{
Reform of computer introduction curriculum system based on Computational Thinking
}

\author{
Jubao Qu, Hongtao Liang \\ School of mathematics and computer, Wuyi University, Wuyishan, Fujian 354300, China \\ qjbok@qq.com
}

Keywords: Computational Thinking, computer introduction, curriculum system, reform

\begin{abstract}
Social progress can not be separated from talents, and an outstanding talent must have very transcendental wisdom, and computational thinking is the key to cultivate this wisdom, the concept of Computational Thinking in the current computer science at home and abroad has been widely concerned, and computational thinking ability has become a modern high-quality talent must. In order to cultivate students'Computational Thinking ability, the course system of computer introduction is reformed in an all-round way, and a feasible reform measure is designed to cultivate students' Computational Thinking ability.
\end{abstract}

\section{Introduction}

Human society cannot leave thinking. It is the source of power for social progress and human evolution. What is the unique thinking in the computer field? Professor Zhou Yizhen of Carnegie Mellon University first introduced the concept of computational thinking. He pointed out that "computational thinking" refers to a series of thinking activities covering the breadth of computer science, such as problem solving, system design, and human behavior understanding, using the basic concepts of computer science. For the students of computer science and technology, the introduction to computer is the first professional basic course to learn since entering university. How to guide a high school student through this course, stimulate the students' enthusiasm for computer professional knowledge, understand the field of computer application and the direction of subject development, master computer science The study method of the course of study and technology specialty, the main course of study of computer science and Technology Specialty in the future, the level to be attained, and the professional ethics and professional accomplishment that should be possessed, thus become the applied technical talents who have the ability to analyze and solve problems. However, around how to achieve such a training goal, the measures taken by different schools are different, so the results are naturally different. Seen from the teaching content, some colleges and universities take the introduction to computer as the "university computer foundation" course for non-computer majors, and regard computer operation knowledge as the main 
teaching content, thus losing the essential attribute of the introduction to computer guiding course; some colleges and universities take the computer science and technology majors students to study in university. The core courses of specialty are compressed and summarized, and then explained respectively by the teaching method of introduction to computer. Obviously, the first kind of content organization is not consistent with the educational goals and functions of computer science and technology specialty itself to computer introduction, and the second kind of content organization is too broad, resulting in the computer introduction course involves too wide a range of knowledge, freshmen can not understand and master all the content [2]. Even if the students can understand the knowledge system, professional direction and characteristics of computer science and technology, the introduction to computer course may not be able to fully enable students to understand, resulting in a sense of embarrassment for the follow-up courses. In fact, mastering this knowledge requires four years of gradual study of the follow-up courses in the university to achieve, not an overnight thing. Therefore, how to design a well-structured and wellstructured computer introduction course is very necessary for the application-oriented undergraduate computer science and technology.

Computing Curricula 1991, jointly issued by ACM and IEEE in the United States, and the subsequent CC2001, CC2004 and CC2005 tutorials, have exerted a tremendous influence on the formulation of teaching plans for computer majors and the standards for training personnel both at home and abroad. This series of tutorials is a long-term follow-up and assessment of the impact of industry, science and technology on the field of computing. The demand for talents and the needs, conditions, development and existing problems of the educational circles for talents' education and training have been put forward. A reference plan for undergraduate teaching of computational science with guiding significance has been put forward. A clear and feasible definition of computational science has been given: "Computer science and technology are algorithmic processes for describing and exchanging information, including their principles." A systematic study of theory, analysis, design, efficiency analysis, implementation and application[4]. The architecture of computer and technical knowledge is divided into 14 major areas, 132 knowledge points, totaling 280 class hours. In order to meet the needs of current technology and application, the original computational disciplines are divided into Computer Science, Computer Engineering, Software Engineering, Information Systems, and I. Five directions, such as information technology, have been devised, and relatively independent curriculum systems and syllabuses for these five disciplines have been designed. These curriculum systems have played a very important role in standardizing and guiding undergraduate computer education, and have gradually become an important basis and programmatic document for the curriculum construction of computer science education circles in various countries. In these tutorials, the requirements and importance of the construction of computer introduction course are pointed out in detail, which makes the construction of computer introduction course content become a focus of discussion in computer education circles. In view of this situation, the Course Research Group of Computer Science and Technology in China put forward China Computing Curricula 2002 in 2002 after studying, digesting and absorbing CC2001 in combination with the development situation of universities, industry and social needs in China. The basic content of the introduction course of computer was clearly pointed out. The outline provides a theoretical basis for the content system construction of computer introduction course. 


\section{Course structure design}

The overall orientation of the school determines the training objectives of each major, and the training objectives of the major determine the teaching objectives of the course. According to the guidance of CCC22002, computer science and technology professionals can be divided into science (computer science), engineering (computer engineering and software engineering) and application (information system and information technology). Wuyi College regards local, applied and distinctive characteristics as the overall orientation of the school, the construction of high-level applied undergraduate colleges with distinctive characteristics as the development goals, and the cultivation of high-quality applied talents with good ideological and moral character, solid professional foundation, innovative spirit and practical ability as the training objectives. It is decided that the goal of talents training in computer science and technology is applied. Therefore, the teaching plan and course content construction of computer introduction course should serve the overall goal of "application-oriented" personnel training, and take information system and information technology as the core of the teaching system of the architecture course.

Figure 1 shows the curriculum structure of computer science and technology. The system consists of general education platform, professional education platform, professional orientation education platform and practical innovation education platform.

\subsection{Training objectives and career planning education and teaching}

Training objectives as a professional compass, after scientific formulation, not only the teacher to seriously implement, but also to students understand their future direction of development. At present, the training goal of computer science and Technology Specialty in our university is to cultivate the students who can meet the needs of social and economic development, have innovative consciousness and entrepreneurship, have a high sense of social responsibility, coordinate the development of knowledge, ability and quality, possess the basic theory, professional knowledge and professional thought of computer science and technology, and master them systematically. Computer software and hardware system development and skills, with the basic ability to analyze and solve problems in the field, with strong practical application ability, with good engineer literacy and career development potential; can be engaged in computer software and hardware design and application development in enterprises, institutions, technology research and development and management departments and other units. Innovative application oriented technical personnel in system integration, maintenance management, training and teaching. In the course of introduction to computer, the first thing is to let students understand the direction of application-oriented talents'efforts and employment, cultivate the knowledge of applicationoriented professional knowledge and skills, and make students understand that the application-oriented talents of computer specialty are commonly referred to as IT talents, explain the employment position of IT talents, and explain the future society's applicationoriented. Strong demand for talent, so that students can have a preliminary judgment of their future professional direction. At the same time, we should have a comprehensive 
understanding of the main courses and the abilities that should be available in applied specialties. Especially, we should realize that applied talents are not skilled talents, and in order to be competent for their work tasks, as well as research-oriented or engineeringoriented training objectives, we also need a systematic and specialized knowledge system and structure to lay a solid professional theoretical foundation for their professional career; during this period, we must also carry out the necessary for students. The education of outlook on life and values, of which the ideological and political education of curriculum is also essential at this stage. To cultivate useful talents who understand technology, are willing to serve, are willing to work without complaint, and serve the country and the people, we must also carry out meticulous ideological and political education.

\subsection{Interest in education and teaching}

The teaching of computer introductory course should give full play to its characteristics and function of guiding study. As mentioned in document [4], it should play the role of "five guides": guiding knowledge, guiding methods, guiding thinking, guiding consciousness and guiding occupation. And I personally believe that in addition to the "five guides," but also should increase a guide interest, no interest, no motivation, will not last, and interest is the best teacher. Therefore, in the process of computer teaching for freshmen, first of all, I stimulate their enthusiasm and interest in learning, and tell them that the way they study in university is different from that in middle school, more depends on independent learning, rather than the passive learning mode instilled in middle school. The demand of modern society and enterprises for talents is not only to see how highly educated you are, how much knowledge you have, but also to see whether you can adapt to the new position and selflearning ability, can be competent for the job you have arranged. In addition to imparting knowledge in the classroom, more students are required to enrich and improve the skills that application-oriented students should possess through independent learning and practice in laboratories, libraries, practice bases, innovative and entrepreneurial places. For applicationoriented students, the future career will face more changes and challenges, technology and knowledge are increasingly updated, more students need to have new knowledge, new technology sensitivity, in order to be able to quickly absorb new technology and combine it with the actual needs. Therefore, cultivating a good habit of autonomous learning is also an important goal of computer introduction course.

\subsection{Basic knowledge education and teaching}

This part constitutes the basic knowledge teaching stage of this course, aiming to form the understanding of computer basic knowledge and the training of basic operating skills. It mainly teaches the history of computer development, application fields, famous computer scientists at home and abroad, famous computer companies, data representation, storage and processing of commonly used operating systems, common software, office software, computer hardware composition and structure, algorithm and programming part mainly explains what is an algorithm, how to Using algorithms to solve scientific problems, algorithm design ideas, programming concepts, methods, software development process, etc. [5]. At this stage, special attention should be paid to the cultivation of students' ability to do 
practical experiments. Because freshmen have uneven foundations and cannot teach too many experiments in theory class, the instructions in the laboratory and students' self-study after class should be arranged in detail so that students can achieve the intended teaching objectives.

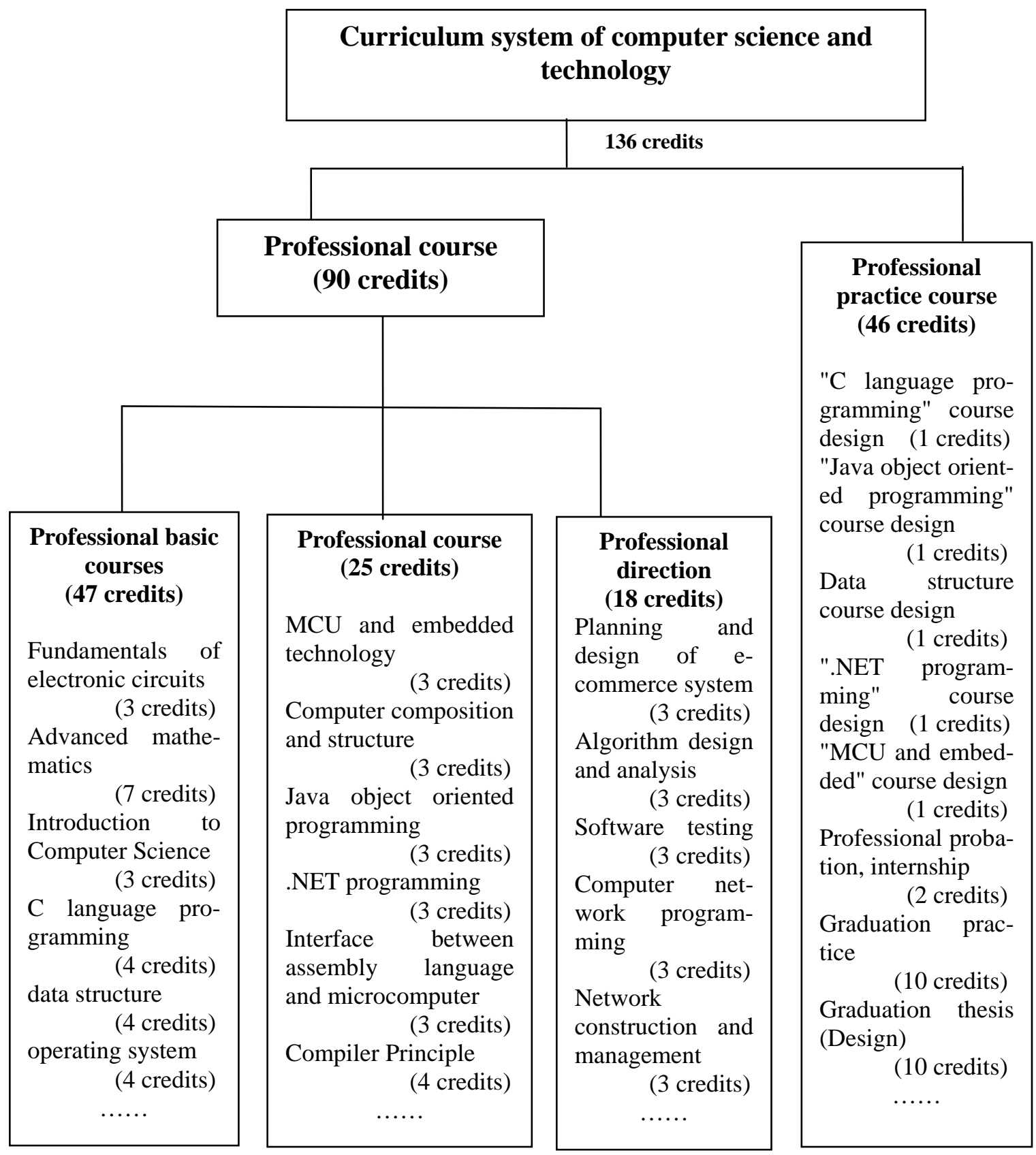

Figure 1. Curriculum system of computer science and technology

\subsection{Professional knowledge education and teaching:}

This part constitutes the professional knowledge teaching stage of this course. It is an overview of the computer professional knowledge that students will learn in the next four 
years, and guides them to know how to learn, how to learn and what is useful in the future. This stage mainly teaches the basic concepts and methods of program design, database basic concepts, data model, SQL language, data management system Acess, hackers and data security, computer network applications, information retrieval, future professional direction courses elective. In this part, we use WYSIWYG software to teach students how to design, debug and run programs quickly. For example, when teaching to the database, we use Access2010 to create and open the database, the design and creation of data tables, the design of forms, queries and reports. When explaining the modern programming technology, we talk about. NET application, we teach students how to quickly cut into the program design and window construction, to stimulate their enthusiasm for programming. And interest, and develop their own simple application software and forms to increase students' sense of achievement. Through the teaching of computer network and security course, we can cultivate students' correct network consciousness, maintain national security, pay attention to the connotation of moral education and serve the socialist cause.

\subsection{New technology application education teaching}

This part of the course is the knowledge extension stage, designed to enable students to understand the latest research areas of computer applications, to have a good perspective on their forthcoming industry, early planning and cultivation of their professional qualities and career planning. The knowledge structure of computer application talents in the future society will put forward higher and more stringent requirements, which not only require them to master this professional knowledge, but also require them to have a broader vision of new knowledge and new technology, can constantly adapt to the changes and expansion of the profession, with a keen sense of innovation and foresight, and with a new perspective. Have a good knowledge of Humanities and Social Sciences and teamwork spirit, so as to lay a solid foundation for future success.

\section{Effect statistics}

In order to further achieve the comprehensive training of students' practical ability, our college computer science and technology specialty participated in IEET certification. The China Institute of Engineering Education (IEET) is the first professional appraisal institution accredited by the Ministry of Education in China. Its main business is to plan and implement the certification of Engineering Education, Information Education (CAC), Technical Education (TAC), Architectural Education (AAC) and Design Education (DAC). 546 departments of 84 universities and colleges in China have participated in IEET certification. Table 1 is for computer science and technology students on the "core competencies and professional curriculum relevance questionnaire statistics", and students returned after graduation practice to fill in, they have a certain amount of work experience and feelings, have some views on their own courses. The data in the table are correlated to 1 and unrelated to 0 . Then the number of correlations between each core competence and each course is counted to get the aggregated data. From the data we can see that the introduction of computer courses in the course of relevance is still relatively accepted by students, but there is still room for further increase. 
Table 1. Questionnaire survey on students' core competencies and professional courses

\begin{tabular}{|c|c|c|c|c|c|c|c|c|}
\hline \multirow[b]{2}{*}{ Professional courses } & \multicolumn{8}{|c|}{ Core competence of professional students } \\
\hline & $\begin{array}{l}\text { Core } \\
\text { compe- } \\
\text { tence } 1\end{array}$ & $\begin{array}{c}\text { Core } \\
\text { compe- } \\
\text { tence } 2\end{array}$ & $\begin{array}{c}\text { Core } \\
\text { compe- } \\
\text { tence } 3\end{array}$ & $\begin{array}{c}\text { Core } \\
\text { compe- } \\
\text { tence } 4\end{array}$ & $\begin{array}{c}\text { Core } \\
\text { compe- } \\
\text { tence } 5\end{array}$ & $\begin{array}{c}\text { Core } \\
\text { compe- } \\
\text { tence } 6\end{array}$ & $\begin{array}{c}\text { Core } \\
\text { compe- } \\
\text { tence } 7\end{array}$ & $\begin{array}{l}\text { Core } \\
\text { compe- } \\
\text { tence } 8\end{array}$ \\
\hline Advanced mathematics & 87 & 81 & 16 & 17 & 17 & 23 & 11 & 18 \\
\hline linear algebra & 90 & 64 & 18 & 13 & 15 & 17 & 16 & 23 \\
\hline digital logic & 83 & 69 & 16 & 26 & 20 & 30 & 31 & 38 \\
\hline $\begin{array}{l}\text { Introduction to } \\
\text { Computer Science }\end{array}$ & 77 & 67 & 69 & 54 & 38 & 51 & 57 & 53 \\
\hline $\begin{array}{c}\text { C language } \\
\text { programming }\end{array}$ & 58 & 64 & 63 & 64 & 33 & 49 & 42 & 37 \\
\hline data structure & 58 & 62 & 65 & 56 & 32 & 26 & 41 & 42 \\
\hline operating system & 45 & 44 & 66 & 64 & 31 & 40 & 38 & 52 \\
\hline Database principle & 61 & 70 & 58 & 47 & 25 & 33 & 34 & 38 \\
\hline software engineering & 43 & 49 & 58 & 32 & 42 & 39 & 49 & 57 \\
\hline $\begin{array}{l}\text { Java object oriented } \\
\text { programming }\end{array}$ & 60 & 70 & 75 & 61 & 31 & 38 & 27 & 26 \\
\hline .NET programming & 57 & 58 & 73 & 60 & 35 & 34 & 18 & 31 \\
\hline Compiling principle & 63 & 55 & 44 & 25 & 48 & 39 & 44 & 21 \\
\hline Single item average & 60.06 & 58.39 & 46.33 & 40.94 & 29.22 & 34.00 & 34.11 & 35.50 \\
\hline $\begin{array}{l}\text { Single item average } \\
\text { ratio }\end{array}$ & $17.74 \%$ & $17.25 \%$ & $13.69 \%$ & $12.09 \%$ & $8.63 \%$ & $10.04 \%$ & $10.08 \%$ & $10.49 \%$ \\
\hline $\begin{array}{c}\mathrm{A} 1+\mathrm{A} 2+\mathrm{A} 3+\mathrm{A} 4: 50- \\
60 \%\end{array}$ & \multicolumn{4}{|c|}{$61.13 \%$} & \multicolumn{4}{|c|}{ Individual $\geqq 5 \%$} \\
\hline Total & \multicolumn{8}{|c|}{$100 \%$} \\
\hline
\end{tabular}

\section{Conclusion}

The teaching reform of Applied Undergraduate Colleges and universities is a long-term task which keeps pace with the times. It has a long way to go. It should not only be in line with the international standards, but also be closely related to the domestic scientific and technological development, social needs and personnel training objectives. Each university is located in a different geographical position and serves different regions, which will inevitably have an impact on the development and promotion of regional economy. How to make the talents trained by colleges and universities adapt to the social and national needs well and quickly is a big problem facing every educator, which must be paid great attention to. After 
years of teaching computer introduction and feedback research on graduating students, it is found that the cultivation of students' learning habits and world outlook in their freshman year is very important, which has a direct impact on the development of University and even the whole life. Therefore, it is very important to attach importance to the teaching and education of computer introduction.

\section{Acknowledgments}

This work was partially supported by Fujian Provincial Higher Education Innovation and Entrepreneurship Education Reform Project(sjzy2017002), Fujian Provincial University "Curriculum Thought" Education and Teaching Reform Project(KC18087), Fujian Provincial Natural Science Foundation Project(2017J01406).

\section{References}

[1] Tan Hongye, Wang Wenjian, Li Ru. Introduction to Computational Thinking and MOOC. Computer Education, 2015 (13): 46-49.

[2] Ren Zi ting. Research and practice of teaching contents of computer introduction course, [J]. software guide, 2013 (2): 12-16.

[3] Carrie Mao, Li Mingdong, Lai Xiaofeng, Dong Wen.Reform and Practice of Computer Introduction Course Based on Computational Thinking [J] Journal of West China Normal University (Natural Science Edition), 2014 (35): 87-90.

[4] China Computer Science and Technology Course 2002 Research Group. China Computer Science and Technology Course 2002 [M]. Beijing: Tsinghua University Press, 2002 (4): 18-23.

[5] Yuan Fang, Wang Bing, Li Jimin and Zhang Ming. Reform the teaching methods and give full play to the "five-leading" role of computer introduction [J].Computer Education, 2011 (1): 56-61. 